\title{
ANÁLISIS
}

\section{Effects of Cross-Border Engineer Exchange on Innovation: Firm-Level Evidence from Hanoi in Vietnam and Calabarzon in the Philippines ${ }^{1}$}

DOI: $10.32870 /$ mycp.v1i1.384

\author{
Tomohiro Machikita \\ Truong Thi Chi Binh \\ Yasushi Ueki
}

\begin{abstract}
$\mathrm{U}$

sing data from a survey to manufacturing firms, this paper attempts to detect sources of new technologies transferred to a well-established industrial district in Calabarzon, the Philippines, and a rapidly growing agglomeration in Hanoi, Vietnam. We find significant effects of exchange of engineers with customer or supplier on improvements in fundamental processes by firms in Hanoi. On the other hand, exchange
\end{abstract}

Artículo recibido el 31 de octubre de 2011 y dictaminado el 27 de febrero de 2012.

1. This paper is one of the results of the research project entitled "Development of Regional Production and Logistics Networks in East Asia," which was organized by the Economic Research Institute for ASEAN and East Asia (ERIA) in fiscal year 2008. The dataset used in this paper was developed by the Institute of Developing Economies (IDE), the Philippine Institute for Development Studies (PIDS), National Statistical Office of the Philippines, and the Institute for Industry Policy and Strategy (IPSI). The views expressed in this paper are those of the authors and do not necessarily reflect the views of the organizations.

Tomohiro Machikita: Research Economist, Institute of Developing Economies (IDE-JETRO) and Visiting Researcher, Asia Research Centre, Copenhagen Business School, Denmark.

Truong Thi Chi Binh: Director, Supporting Industry Enterprise Development Center (SIEDC), for Industrial Policy and Strategy Institute, Ministry of Industry and Trade of Vietnam.

Yasushi Ueki: Research Fellow, Inter-disciplinary Studies Center, Institute of Developing Economies, Japan External Trade Organization (IDE-JETRO). 
of engineers significantly affects improvements in production and quality control of products newly introduced by firms in Calabarzon. The difference in the effects of exchanging engineers between the two industrial districts indicates difference in the stages of industrial development.

Keywords: interaction among engineers, innovation, technology transfer.

\section{Resumen}

Utilizando los resultados de una encuesta aplicada a firmas manufactureras, en este artículo se busca identificar las fuentes de la transferencia tecnológica en un distrito industrial consolidado en Calabarzón, en Filipinas, y en una aglomeración de rápido crecimiento en Hanoi, Vietnam. Encontramos efectos significativos por medio del intercambio de ingenieros entre empresas clientes y proveedoras, en la mejora de procesos fundamentales en las firmas en Hanoi. Por otro lado, el intercambio de ingenieros afecta de manera significativa para lograr mejoras en la producción y en el control de calidad de productos nuevos introducidos por las firmas en Calabarzón. La diferencia de los efectos del intercambio de ingenieros entre los dos distritos industriales indica la diferencia en los grados relativos de desarrollo industrial.

Palabras clave: interacción entre ingenieros, innovación, transferencia tecnológica.

JeL Classification: O31, O32, R12.

\section{Introduction}

The objective of this paper is to find the sources of transfer of technology based on a survey at firm-level data in two manufacturing sectors of Hanoi in Vietnam and Calabarzon in the Philippines. ${ }^{2}$ Detecting sources of productivity improvements have been a matter of concern for academics and policy makers. For example, Foster, Haltiwanger, and Krizan (2001) decompose the sources of aggregate productivity growth in the U. S. manufacturing into: (1) productivity gain within each plant, (2) change in output shares, and (3) entry and exit. The latter two effects explain 50 percent of the aggregate growth. For their part, Lentz and Mortensen (2008) show the selection effect accounts for

2. Calabarzon is a region in the Philippines composed of the provinces of Cavite, Laguna, Batangas, Rizal, and Quezon. 
53 percent of aggregate growth in Denmark.

However the literature has not yet accumulated knowledge on plant-level productivity gains driven by innovation. To do so, by using data developed from a survey to establishments in the manufacturing sector, this paper attempts to identify sources of knowledge exchangeable through production linkages to introduce new products or
It can be assumed that exchange of knowledge through face-to-face communications among engineers is a key determinant of achieving product and process innovations because this is a direct channel of transferring tacit knowledge services or to enhance QCD performances; i. e. improve quality control (Q), reduce costs $(C)$ and reduce delivery time (D).

It can be assumed that exchange of knowledge through face-to-face communications among engineers is a key determinant of achieving product and process innovations because this is a direct channel of transferring tacit knowledge. In this analytical framework, vertically integrated firms through business transactions can exchange ideas by dispatching engineers to or accepting them from their business partners. To examine this hypothesis, indepth information on firm-specific transactions is indispensable. As applied by insider econometrics like Ichiniowski, et al. (1997), Hamilton, et al. (2003), and Mas and Moretti (2009), this paper developed an original questionnaire survey to manufacturing firms in Hanoi and Calabarzon. Comparative studies between the two industrial districts with different characteristics will enable to identify differences in sources of new technologies according to innovation types and absorptive capacity levels.

By applying probit estimations, this paper verifies significant effects of exchange of engineers by firms: (1) in Hanoi with customers in Vietnam and Japan and suppliers in Vietnam and China and their effect on QCD performances, and (2) in Calabarzon with customers in Japan and suppliers in China and their effect on introduction of new products and improvements in quality control for new products.

The structure of this paper is the following. Section II introduces hypothesis, the model and the data. Section III presents summary statistics. Empirical 
results are explained in Section IV. Knowledge integration in Asia through economic integration is discussed in Section V. Section VI provides conclusion.

\section{Empirical Strategy}

\section{Hypothesis}

Factors that can motivate firms to make efforts for improving management and achieve innovation have been major concerns for researchers and policy makers. For instance, Truong (2010), based on her in-depth case studies of firms in Vietnam, emphasize customers' requests are one of the important motivations for Vietnamese firms to innovate.

To illustrate how customer-supplier relationships promote innovations, relationships between a firm $X$ and its customer $C_{x}$ and between the firm $X$ and its supplier $S_{x}$ are considered. As depict in Figure 1 , the firm $C_{x}$ has concerns about QCD performances of the firm $X$, from which the firm $C_{x}$ purchases parts and materials, because $Q C D$ performances of the firm $X$ could affect $Q C D$ performances of $C_{x}$. Therefore the firm $C_{x}$ will require the firm $X$ to satisfy QCD standards specified by the firm $C_{x}$, giving the firm $X$ technical assistance or cooperating with it to achieve QCD standards of the firm $C_{x}$. The firm $C_{x}$ can also encourage the firm $\mathrm{X}$ to make efforts for satisfying the standards by stimulating competition with potential suppliers.

Faced with requirements regarding $Q C D$ from its customer $C_{x}$, the firm $X$ on the other hand needs to make use of its internal resources to fulfill them. If the firm $X$ does not have sufficient resources, the firm needs to seek for external resources that can be available through collaboration with its supplier $S_{x}$ to satisfy requests from its customer $C_{x}$. Thus, the relationship with supplier should be an important factor that can determine resources available for the firm $\mathrm{X}$ to achieve targeted upgrading or incremental innovations that are set according its customer's requirements (Figure 1 ).

In the same way of thinking, when the firm $X$ introduces a new product to satisfy demands from its customer $C_{x}$, this firm will need to introduce knowledge and technologies indispensable to develop it or to improve processes for manufacturing in cooperation with its customer $C_{x}$ or supplier $S_{x}$.

It can be postulated that the resulting geographical distribution of such business partners of firm $\mathrm{X}$ can be dependent on the following three factors. First is the availability of resources within firm X or the place where firm X lo- 
Figure 1

Conceptual Framework

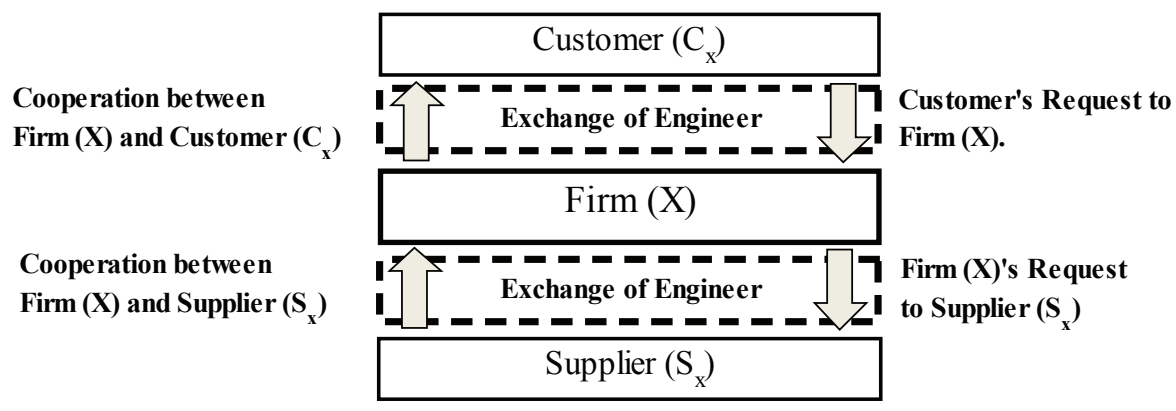

Source: authors.

cates. Firms without sufficient internal resources for innovation will cooperate with external partners and introduce knowledge and technologies necessary for satisfying requirements from their customers or achieving innovations (Machikita and Ueki, 2010c). The geographical distribution is also affected by the availability of local resources.

Second is so called transaction cost. Exchange of knowledge is costly. Especially when knowledge is not "encoded" (Polanyi, 1966, 1967) to be exchanged via information technologies, firms necessitate face-to-face communication. Machikita and Ueki (2010d) verify significant effects of face-to-face communications on process innovations. To exchange such tacit technical knowledge, especially if it is of the complex type, face-to-face communication among engineers can be the most efficient way. When transportation costs are high for engineers to move, firms will prefer local inter-firm knowledge transfer. Firms also can take advantage of inter-regional knowledge transfer when transportation costs are so low that engineers can visit their counterparts frequently.

Third is the capability of firms necessary for overcoming transaction costs and benefiting from external resources. Various transaction costs, including costs for knowledge exchange, affect the way in which businesses select partners and cooperate with customers or suppliers. Previous studies have focused on geographical proximities to consider such effects of transaction costs. Kimura (2009) proposes the concept of four layers of transactions in production and distribution networks stratified in terms of gate-to-gate lead time and the frequency of delivery. Machikita and Ueki (2010a) verify that 
firm-level capabilities and transaction costs associated with specific inter-firm relationships would influence the distance between customers and suppliers, using firm-level data. Machikita and Ueki (2010b) also empirically examine the difference between importers and non-importers in the effects of geographic proximity on the procurement process.

It is also assumed that firm-level capability will have a considerable influence on performances of innovative activities by firms. As discussed by Cohen and Levinthal (1990), the ability of a firm to recognize the value of external information and apply it to commercial purposes is crucial to its innovation performance. These imply that firms in Hanoi and Calabarzon will achieve different innovations by accessing same sources of knowledge. These two groups of firms that will have different absorptive capacity will also seek for different sources of knowledge appropriate to achieve different innovations. Challenges faced by firms and their managerial capabilities will determine the content of knowledge to be exchanged through face-to-face communication and the location of their more suitable partners. Firms in countries with weak supporting industries like Vietnam will need international technology transfers to obtain fundamental capabilities of QCD to enter into international production networks governed by MNCs. In contract, firms in relatively developed industrial districts like the ones in the Philippines will be able to exchange knowledge with firms within the same agglomeration area or combine the local knowledge with technologies transferred from developed countries such as Japan and the United States to develop new products, shorten life cycles of their products or introduce them without technical problems from the beginning of their commercial production (Saxenian, 1996, 2006).

\section{The Model}

Based on these hypotheses, this paper attempts a comparative study between firms in Hanoi, Vietnam and those in Calabarzon, in the Philippines where firms with different absorptive capabilities will locate. To empirically detect sources of information for process and product innovations and their influences on innovations, this paper explores the use of the following binary probit estimation in modeling the relation between innovations and exchanges of engineers with suppliers or customers that firms in Hanoi and Calabarzon have transactions with. 


$$
\operatorname{Probit}\left(I N N O V_{\mathrm{ik}}\right)=\alpha+\beta E X_{\mathrm{i}}+\gamma x_{\mathrm{i}}+u_{\mathrm{i}} .
$$

The dependent variable INNOV is an indicator for process or product innovation $(k)$. The variables for process innovations are coded 1 if the firm (i) adopted international standards between 2006 and 2008 or improved QCD performances between 2007 and 2008, otherwise 0. In the estimation, five variables are identified as indicators of process innovation: (1) Adoption of international standards (STAN); (2) Product quality improved (Q); (3) The number of product defects was reduced ( $P D)$; (4) Production cost decreased $(C)$; and (5) Lead-time (the period between a customer's order and delivery of product) was reduced $(D)$. In addition, the dummy variable $Q C$ is defined as the case of improvement of quality control and cost reduction at the same time. In the same manner, the dummy variable $Q C D$ is coded 1 if the firm (i) improved $Q, C$ and $D$ at once.

Among the dependent variable INNOV includes indicators for product innovations achieved by firms in Calabarzon, which are coded 1 if the firm ( $i$ ) introduced (1) a new product or service between 2006 and 2008 (PROD), (2) one into new market (MARKET), or (3) one based on new technologies (TECH). In addition, the dummy variables $Q P R O D\left(P D_{-} P R O D\right)$ are defined to consider the cases that the firms achieved $Q(P D)$ and $P R O D$ simultaneously. In the same manner, $Q$ MARKET (PD_MARKET) and $Q$ TECH (PD_TECH) are defined.

The independent variables are $E X$ and other control variables. The variable $E X$ is a dummy variable taking 1 if the firm (i) exchanges engineer with its main supplier or customer. The variables represented by $x_{i}$ are other control variables such as $R \& D$, asset size, nationality and industry. The variable ASSET represents the size of the assets that belong to the firm. The firms responding to the survey were asked to indicate the value of their total assets by choosing one of the 10 categories. ${ }^{3}$ The variable ASSET is defined as the median value of each category. For example, if the respondent chose "10,000-24,999 U. S. dollars," this ASSET is taken as 17,500 U. S. dollars.

The variable $R \& D$ is a dummy coded 1 if the firm (i) carries out $R \& D$. This variable is introduced into the regression of product innovation, supposing

3. (1) less than 10,000 U. S. dollars; (2) 10,000-24,999 U. S. dollars; (3) 25,000-49,999 U. S. dollars; (4) 50,000-74,999 U. S. dollars; (5) 75,000-99,999 U. S. dollars; (6) 100,000-499,999 U. S. dollars; (7) 500,000-999,999 U. S. dollars; (8) 1 million-4.9 million U. S. dollars; (9) 5-9.9 million U. S. dollars; (10) 10 million U. S. dollars and above. 
that $R \& D$ is relevant to develop new products and processes and that $\mathrm{QCD}$ performance are more dependent on daily group efforts for improvements.

The variable LOCAL is a dummy variable that is coded 1 if the firm (i) is indigenous (100\% local capital). There are five industry dummy variables: LIGHT; CHEMICAL; METAL; ELECTRONICS; and MACHINE. The variable LIGHT includes food and textiles industries. METAL includes industries of iron, steel and metal products. The variable CHEMICAL corresponds to chemicals and chemical products. Manufacturing of electronics or electronic components other than computers and computer parts are categorized as ELECTRONICS while the other machinery products are aggregated into the variable MACHINE.

Details of the dependent variables INNOV, independent variables EX and other control variables are listed in Appendix Table A1.

\section{The Data}

The dataset used in this paper was created from the ERIA 2008 Survey on Production and Logistics Networks (SPLN) for manufacturing firms in two industrial districts in Asia: Hanoi and surrounding areas in Vietnam; and Calabarzon in the Philippines. The sample population is restricted to selected manufacturing districts. The survey was developed to collect firm-level data on production and logistics networks, with the aim of pinpointing sources of knowledge transfer facilitated by economic integration in Asia. An original questionnaire was designed solely for the survey by reference to the Oslo Manual developed by the Organization for Economic Co-operation and Development (OECD). The questionnaire was distributed in December 2008 and January 2009. A total of 138 firms in Hanoi and 204 firms in Calabarzon agreed to participate in the survey. ${ }^{4}$

Table 1 presents characteristics of the firms that responded to the survey. By nationality of the firms, $40.6 \%$ of the respondents in Vietnam are local. This percentage for Calabarzon is $50.5 \%$, which is significantly higher than Hanoi.

The average asset size, or the mean of the variable ASSET, is about 5.6 million U. S. dollars for Vietnam, suggesting that the respondents in Hanoi are not small firms in terms of asset size according to Vietnam's definition of

4. The same questionnaire survey was conducted in four Southeast Asian countries including Jabodetabek (i. e., Jakarta, Bogor, Depok, Tangerang, and Bekasi), Indonesia, and Greater Bangkok area, Thailand (Limskul, 2009). 
SME. ${ }^{5}$ In addition, the average size of the firms in Hanoi is larger than those in Calabarzon.

\section{Table 1}

Characteristics of Firms in Hanoi and Calabarzon

\begin{tabular}{|c|c|c|c|c|c|c|c|}
\hline \multirow[b]{2}{*}{ Variable } & \multicolumn{2}{|c|}{ Whole Sample } & \multicolumn{2}{|c|}{ Hanoi } & \multicolumn{2}{|c|}{ Calabarzon } & \multirow{2}{*}{$\begin{array}{c}\text { Difference } \\
\text { (t-test) }\end{array}$} \\
\hline & Obs. & Mean & Obs. & $\operatorname{Mean}(v n)$ & Obs. & Mean(ph) & \\
\hline$R \& D$ & 342 & 0.193 & 138 & 0.116 & 204 & 0.245 & --- \\
\hline Asset & 332 & $4,311,687$ & 129 & $5,550,252$ & 203 & $3,524,618$ & +++ \\
\hline Local & 342 & 0.465 & 138 & 0.406 & 204 & 0.505 & -- \\
\hline Light & 342 & 0.269 & 138 & 0.101 & 204 & 0.382 & --- \\
\hline Chemical & 342 & 0.114 & 138 & 0.130 & 204 & 0.103 & \\
\hline Metal & 342 & 0.117 & 138 & 0.138 & 204 & 0.103 & \\
\hline Electronics & 342 & 0.146 & 138 & 0.145 & 204 & 0.147 & \\
\hline Machine & 342 & 0.155 & 138 & 0.217 & 204 & 0.113 & +++ \\
\hline
\end{tabular}

Note:,,++++++ indicate the null hypothesis $\mathrm{H}_{0}: \operatorname{Mean}(\mathrm{VN})=\mathrm{Mean}(\mathrm{PH})$ tested against the alternative hypothesis $\mathrm{H}_{\mathrm{a}}$ : Mean $(\mathrm{VN})>\operatorname{Mean}(\mathrm{PH})$ is significant at the $1 \%, 5 \%$ and $10 \%$ level respectively. ---, -- and - indicate the null hypothesis $\mathrm{H}_{0}$ tested against the alternative hypothesis $\mathrm{H}_{\mathrm{a}}: \operatorname{Mean}(\mathrm{VN})<\operatorname{Mean}(\mathrm{PH})$ is significant at the $1 \%, 5 \%$ and $10 \%$ level respectively.

Source: ERIA 2008 SPLN.

There are not statistically significant differences in main business activities between firms in Hanoi and Calabarzon, except light and machinery industries. More firms in Calabarzon are engaged in manufacturing light products including food and textiles (38.2\%), while firms in Hanoi (21.7\%) produce mainly machineries other than electronics. Even though firms in Calabarzon hold less assets and are dedicated to light industries, they perform more R\&D activities than their counterparts in Hanoi. This may reflect differences in innovation capacities between the two industrial districts.

5. Government Decree 90/2001/ND-CP, dated 23 November 2001, defines SMEs as independent production and business establishments, with registered capital not exceeding VND 10 billion or annual labor not exceeding 300 people (http://www.business.gov.vn/asmed. aspx?id=49\&LangType=1033, accessed on 11 August 2010). 


\section{Production Linkages and Innovation in Hanoi and Calabarzon}

\section{Agglomeration in Hanoi and Calabarzon}

Agglomeration in Hanoi is a recent phenomenon. Formation of the industrial district in the area was accelerated by Japan's official development assistance (ODA) for renovating transportation infrastructure in the 1990s such as Hai Phong Port and National Highway No.5 which connects Hanoi and Hai Phong. Such physical infrastructure is a statistically significant factor that affected decisions made by firms on investments into this region (Truong, 2008). Additionally, it is said that foreign direct investment (FDI) made by large MNCs, especially Canon's new plant for assembling printers in the Thang Long Industrial Park, generated a virtuous circle of investment, especially by Japanese MNCs (Kuchiki and Tsuji, 2008).

Reflecting this historical progress of industrial development in Hanoi, the respondents to the survey are relatively new. Some $72.0 \%$ of the respondents (95 of 132 firms) were established in 2004 or later. This percentage is much higher for MNCs/JVs (82.5\% or 66 of 80 ). Even more than half of the indigenous respondents (55.8\% or 29 of 52 ) started operations in this period. Figure 2 indicates this rapid agglomeration of the manufacturing sector in Hanoi, making comparison with more sluggish industrial district in Calabarzon, where half of the respondents had already been established in or before 1995 .

\section{Linkages with Main Customer and Supplier}

As shown in Figure 2, industrial development in Hanoi is at an early stage, compared to Calabarzon. There are not well-established supporting industries in Hanoi. But Hanoi is situated more than $1,700 \mathrm{~km}$ away from Ho Chi Minh City where are the largest industrial district in Vietnam. In addition, nationwide expressway networks in Vietnam are in the planning stage or under construction. Thus, firms that established their assembly processes in Hanoi are forced to need to purchase raw materials and parts from neighboring countries, especially at the beginning of factory operation. As a result, imports of intermediate goods from Guangdong or Hong Kong through Hai Phong Port have been increasing recently (Ueki, 2010).

Table 2 presents such situation. Some $42.9 \%$ of the firms in Hanoi have their main suppliers in China, while suppliers in Vietnam and Japan are im- 
Figure 2

Year of Establishment (Cumulative Total)

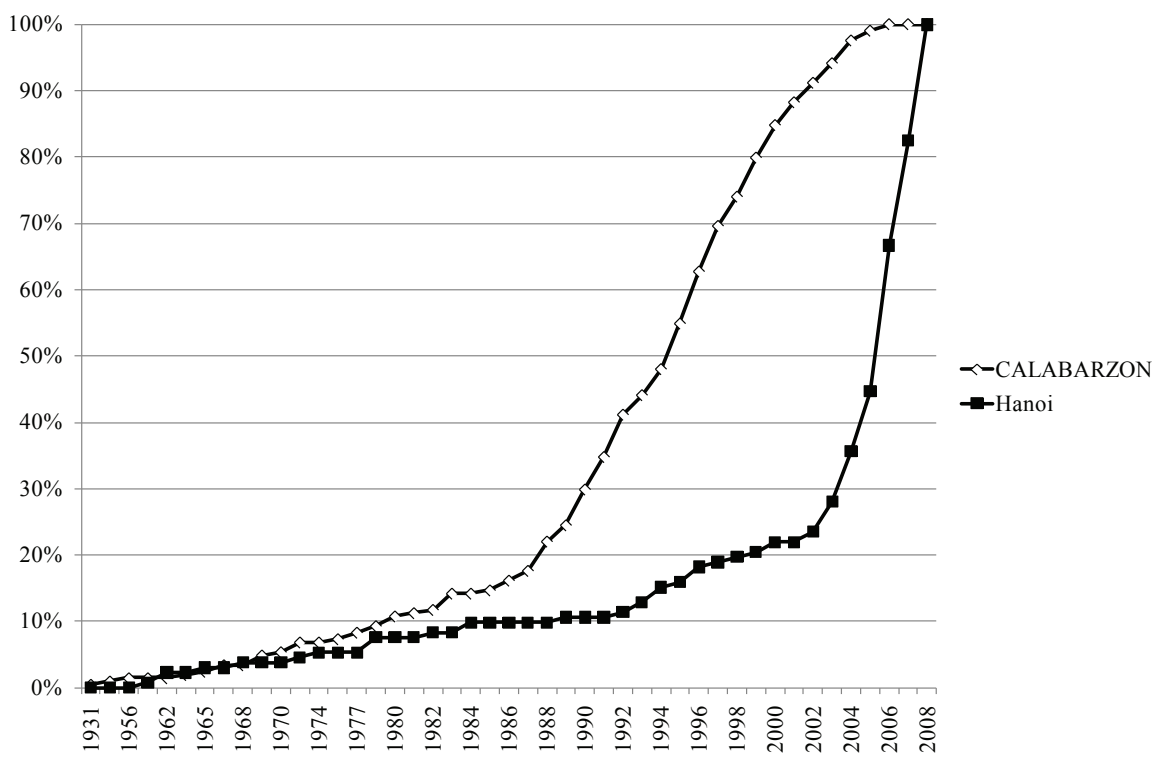

Source: ERIA 2008 SPLN.

portant for about $20 \%$ of them respectively. On the other hand, their main customers are concentrated in Vietnam and Japan. Contrary to Hanoi, firms in Calabarzon are linked to customers and suppliers in the Philippines. Some $44.0 \%$ and $55.7 \%$ of the respondents in the region have their main supplier and customer in this country.

An additional characteristic in the production networks of firms in Calabarzon have closer linkages with customers in developed countries such as European Union and the United States. On the other hand, firms in Hanoi have more business transactions with customers in Japan and are also more dependent on suppliers and customers in China than those in Calabarzon.

Exchange of Engineer with Main Customer and Supplier

This paper emphasizes exchanges of engineer as a potential channel of transferring technologies and information. The survey asked respondents if they 
Table 2

Locations of Main Customer and Supplier

\begin{tabular}{lccccccc}
\hline & \multicolumn{2}{c}{ Whole Sample } & \multicolumn{2}{c}{ Hanoi } & \multicolumn{2}{c}{ Calabarzon } & Difference \\
\cline { 2 - 6 } Variable & Obs. & Mean & Obs. & Mean(VN) & Obs. & Mean(PH) & (t-test) \\
\hline <Main Customer> & & & & & & & \\
LOCAL_c & 283 & 0.527 & 98 & 0.469 & 185 & 0.557 & - \\
JP_c & 283 & 0.205 & 98 & 0.337 & 185 & 0.135 & +++ \\
CN_c & 283 & 0.032 & 98 & 0.071 & 185 & 0.011 & +++ \\
EASEA_c & 283 & 0.049 & 98 & 0.051 & 185 & 0.049 & \\
EUUS_c & 283 & 0.166 & 98 & 0.061 & 185 & 0.222 & - -- \\
<Main Supplier> & & & & & & & \\
LOCAL_s & 259 & 0.355 & 91 & 0.198 & 168 & 0.440 & -- \\
JP_s & 259 & 0.170 & 91 & 0.198 & 168 & 0.155 & \\
CN_s & 259 & 0.236 & 91 & 0.429 & 168 & 0.131 & +++ \\
EASEA_s & 259 & 0.151 & 91 & 0.121 & 168 & 0.167 & \\
EUUS_s & 259 & 0.069 & 91 & 0.044 & 168 & 0.083 & \\
\hline
\end{tabular}

Note: The same as in Table 1.

Source: ERIA 2008 SPLN.

dispatch their engineers to their main supplier (customer) or accept engineers from their supplier (customer). Exchange of engineers is defined if the firms accept or dispatch engineers.

Table 3 summarizes the implementation of exchanging engineers with customer or supplier by its location. Firms in Hanoi have more experiences of doing it, especially with their main customer in Asia, than those in Calabarzon.

Regarding customers of the firms surveyed, both in Hanoi and Calabarzon, domestic firms are the main partners: $32.7 \%$ for Hanoi and $22.7 \%$ for Calabarzon and they do exchange engineers. Domestic customers are followed by Japanese customers. About one third of the firms in Hanoi exchange engineers with customers in Japan, and $10.8 \%$ do so in Calabarzon. In sum, geographical distribution of the customers is an important element in determining the exchange of engineers.

On the other hand, firms do not seek technical information from their main domestic suppliers. Their face-to-face relationships with engineers of their main domestic suppliers do not necessarily reflect transactions of goods with them. Only about $8 \%$ of the firms in Hanoi and Calabarzon exchange engineers with domestic suppliers even though $19.8 \%$ of those in Hanoi and 
$44.0 \%$ of those in Calabarzon recognize domestic suppliers as main sources of inputs.

\section{Table 3}

Exchange of Engineer with Main Customer and Supplier

\begin{tabular}{|c|c|c|c|c|c|c|c|}
\hline \multirow[b]{2}{*}{ Variable } & \multicolumn{2}{|c|}{ Whole Sample } & \multicolumn{2}{|r|}{ Hanoi } & \multicolumn{2}{|c|}{ Calabarzon } & \multirow{2}{*}{$\begin{array}{c}\text { Difference } \\
\text { (t-test) }\end{array}$} \\
\hline & Obs. & Mean & Obs. & $\operatorname{Mean}(v n)$ & Obs. & Mean(ph) & \\
\hline \multicolumn{8}{|c|}{ <Main Customer $>$} \\
\hline EX_LOCAL_c & 283 & 0.261 & 98 & 0.327 & 185 & 0.227 & ++ \\
\hline EX_JP_c & 283 & 0.180 & 98 & 0.316 & 185 & 0.108 & +++ \\
\hline EX_CN_c & 283 & 0.021 & 98 & 0.061 & 185 & 0 & +++ \\
\hline EX_EASEA_c & 283 & 0.028 & 98 & 0.051 & 185 & 0.016 & ++ \\
\hline EX_EUUS_c & 283 & 0.064 & 98 & 0.061 & 185 & 0.065 & \\
\hline \multicolumn{8}{|l|}{ <Main Supplier > } \\
\hline EX_LOCAL_s & 259 & 0.085 & 91 & 0.088 & 168 & 0.083 & \\
\hline EX_JP_s & 259 & 0.139 & 91 & 0.176 & 168 & 0.119 & \\
\hline EX_CN_s & 259 & 0.120 & 91 & 0.275 & 168 & 0.036 & +++ \\
\hline EX_EASEA_s & 259 & 0.069 & 91 & 0.077 & 168 & 0.065 & \\
\hline EX_EUUS_s & 259 & 0.039 & 91 & 0.033 & 168 & 0.042 & \\
\hline
\end{tabular}

Note: The same as in Table 1.

Source: ERIA 2008 SPLN.

However, regarding foreign suppliers, 27.5\% of the respondents in Hanoi considered that suppliers in China are important source of information and technology through face-to-face communications. For those in Calabarzon, suppliers in Japan are main partners: $11.9 \%$ of them do exchange information through exchange of engineers. Suppliers in Japan are also the second most important source of knowledge through the exchange of engineers in Hanoi. From this survey information, we can infer that firms in Hanoi and Calabarzon have close interactions with their suppliers and customers in Japan.

\section{Innovations}

Firms can take advantage of technical information acquired through faceto-face interactions with their customer and supplier to achieve efficiently innovations in processes and products. Table 4 shows performances of innovation by the respondents. 
The firms in Hanoi improved processes more frequently than the firms in Calabarzon, while the latter achieved better results of introducing a new product, or product innovations, than the former. Exceptionally among the types of process improvements, the higher percentages of the firms in Calabarzon improved quality control than those in Hanoi. There is not a statistically significant difference in the probability of reducing product defects between these firms in the two industrial areas.

Table 4

Process and Product Innovations

\begin{tabular}{|c|c|c|c|c|c|c|c|}
\hline \multirow[b]{2}{*}{ Variable } & \multicolumn{2}{|c|}{ Whole Sample } & \multicolumn{2}{|c|}{ Hanoi } & \multicolumn{2}{|c|}{ Calabarzon } & \multirow{2}{*}{$\begin{array}{c}\text { Difference } \\
\text { (t-test) }\end{array}$} \\
\hline & Obs. & Mean & Obs. & $\operatorname{Mean}(\mathrm{VN})$ & Obs. & $\operatorname{Mean}(\mathrm{PH})$ & \\
\hline \multicolumn{8}{|c|}{$<$ Process Innovation $>$} \\
\hline STAN & 342 & 0.556 & 138 & 0.659 & 204 & 0.485 & +++ \\
\hline Q & 342 & 0.751 & 138 & 0.659 & 204 & 0.814 & --- \\
\hline PD & 342 & 0.731 & 138 & 0.717 & 204 & 0.740 & \\
\hline C & 342 & 0.491 & 138 & 0.739 & 204 & 0.324 & +++ \\
\hline D & 342 & 0.602 & 138 & 0.710 & 204 & 0.529 & +++ \\
\hline QC & 342 & 0.427 & 138 & 0.616 & 204 & 0.299 & +++ \\
\hline QCD & 342 & 0.365 & 138 & 0.558 & 204 & 0.235 & +++ \\
\hline \multicolumn{8}{|c|}{$<$ Product Innovation $>$} \\
\hline PROD & 342 & 0.421 & 138 & 0.283 & 204 & 0.515 & --- \\
\hline MARKET & 342 & 0.073 & 138 & 0.036 & 204 & 0.098 & -- \\
\hline $\mathrm{TECH}$ & 342 & 0.120 & 138 & 0.080 & 204 & 0.147 & -- \\
\hline \multicolumn{8}{|c|}{$<$ Product Innovation x Process Innovation $>$} \\
\hline Q PROD & 342 & 0.348 & 138 & 0.210 & 204 & 0.441 & --- \\
\hline PD_PROD & 342 & 0.345 & 138 & 0.239 & 204 & 0.417 & --- \\
\hline Q MARKET & 342 & 0.070 & 138 & 0.036 & 204 & 0.093 & -- \\
\hline PD_MARKET & 342 & 0.064 & 138 & 0.036 & 204 & 0.083 & -- \\
\hline Q TECH & 342 & 0.102 & 138 & 0.051 & 204 & 0.137 & --- \\
\hline PD_TECH & 342 & 0.105 & 138 & 0.072 & 204 & 0.127 & -- \\
\hline
\end{tabular}

Note: The same as in Table 1.

Source: ERIA 2008 SPLN.

Such differences may reflect differences in developmental stages of Hanoi and Calabarzon and comparative advantages, or in business challenges that firms are faced with. The firms in Hanoi are relatively so new that they need 
to enhance fundamental capabilities of process controls that are essential to participate in international production networks, keeping their comparative advantage in terms of labor costs. Therefore, more firms in Hanoi make efforts to adopt international standards, reduce production costs, reduce time for delivery and achieve improve $\mathrm{Q}, \mathrm{C}$, and $\mathrm{D}$ at one time.

The firms in Calabarzon more experienced in the international market have basic managerial capabilities to meet international standards for QCD. But they have lost comparative advantages in terms of costs against $C$ hina and other emerging economies in Southeast Asia including Vietnam. They need to enhance their strengths in quality and production control, fostering R\&D capabilities. Therefore, they shorten product cycles and the period necessary for starting commercial production of new products, lowering product defect rates or improving qualities. As a result, more firms in Calabarzon introduce new products and improve quality control $(Q P R O D)$ or reduce product defects (PD_PROD) simultaneously.

\section{Empirical Result}

In this section, we report the regression results regarding innovation in processes as a result of exchanges of engineers. Then based on the summary statistics shown above, the regressions for Calabarzon show the effects of inter-firm face-to-face communications with domestic customers and suppliers as well as with foreign customers and suppliers in Japan and suppliers in China. As product innovations by firms in Hanoi are not explained by the model, the corresponding results are not reported in this paper.

\section{Process Innovations by Firms in Hanoi}

Table 5 presents correlations between innovations in processes by firms in Hanoi and their exchange of engineers with customers in Japan and Vietnam and suppliers in Vietnam, Japan, and China. ${ }^{6}$

6. The same model is also applied to process innovations by firms in Calabarzon (Table A2). Only the coefficient on exchange of engineer with domestic supplier is positively significant at the $5 \%$ level, supporting a common perception about importance of geographical proximity to suppliers to make delivery management efficient. 
As shown in the column (1) of Table 5, the coefficient on exchange of engineers with suppliers in China is positive and statistically significant at the $1 \%$ level, indicating that engineers working for the firms in Hanoi adopt international standards in technical cooperation with engineers from their main suppliers in China.

Exchanges of engineer with customers in Vietnam and Japan also encourage firms in Hanoi to improve quality control. The coefficient on exchange of engineers with customers in Vietnam is positively significant at the $1 \%$ level. Exchange of engineers with customers in Japan also has a positive effect on improvement in quality control at the $5 \%$ level of significance (column (2)). Japanese customers are the most quality-conscious in the world. They dispatch their engineers to their business partners or accept engineers from their partners periodically, irregularly or in each problematic case.

Cooperation with customers in Japan also helps firms in Hanoi decrease product defects. The coefficient on exchange of engineer with customer in Japan is positively significant at the $10 \%$ level (column (3)).

The column (4) of Table 5 also presents positive and significant effects on cost reduction of exchange of engineers with customers in Japan at the $10 \%$ level and that with suppliers in Vietnam at the $5 \%$ level. This result indicates that firms in Japanese can benefit from cheap labor forces in Vietnam when firms in Hanoi collaborate through face-to-face communication with customers in Japan.

Firms improving quality control and reducing costs simultaneously (QC) take full advantage of knowledge exchanges with their customers and suppliers in Vietnam, and customers in Japan, which have positively significant effects at the $5 \%, 1 \%$ and $10 \%$ levels respectively as shown in the columns (6) of Table 5.

The estimation result for QCD in the column (7) that is similar to that for QC, in particular the positively significant coefficient on suppliers in China at the $10 \%$ level, indicates the importance of geographical proximity to sources of inputs and trade facilitation for improving lead-time or delivery.

These estimation results show the factors that lie behind the location choice made by firms using Hanoi as an assembling base. Firms can use various sources of inputs from local sources and China to ship products to markets in Asia including Vietnam and Japan. This enables firms to optimize procurements of raw materials and parts and decrease labor costs by using Vietnamese workers. In addition, closer relationships involving exchange of 


\section{Table 5}

Effects of Exchanging Engineer with Main Customer and upplier on Process Innovations by Firms in Hanoi

\begin{tabular}{|c|c|c|c|c|c|c|c|}
\hline & (1) & (2) & (3) & (4) & (5) & (6) & (7) \\
\hline & STAN & $Q$ & $P D$ & C & $D$ & $Q C$ & $Q C D$ \\
\hline$\langle\mathrm{EX}\rangle$ & & & & & & & \\
\hline EX_LOCAL_c & 0.626 & $1.564^{* * *}$ & 0.567 & 0.108 & 0.005 & $0.973^{* *}$ & $0.874^{*}$ \\
\hline & $(0.474)$ & $(0.557)$ & $(0.473)$ & $(0.428)$ & $(0.457)$ & $(0.494)$ & $(0.530)$ \\
\hline EX_JP_c & 0.800 & $1.223^{* *}$ & $0.834^{*}$ & $0.893^{*}$ & 0.830 & $1.054^{*}$ & $1.404^{* *}$ \\
\hline & $(0.588)$ & $(0.599)$ & $(0.502)$ & $(0.541)$ & $(0.525)$ & $(0.554)$ & $(0.604)$ \\
\hline EX_LOCAL_s & 1.337 & & & $1.390^{* *}$ & & $3.056^{* * *}$ & $3.531^{* * *}$ \\
\hline & $(0.833)$ & & & $(0.657)$ & & $(0.779)$ & (0.799) \\
\hline EX_JP_s & 0.234 & -0.607 & -0.205 & -0.213 & -0.008 & -0.224 & -0.295 \\
\hline & $(0.726)$ & $(0.727)$ & $(0.626)$ & (0.631) & $(0.644)$ & (0.668) & $(0.718)$ \\
\hline EX_CN_s & $2.254^{* * *}$ & 0.262 & 0.073 & 0.270 & 0.504 & 0.398 & $0.859^{*}$ \\
\hline & $(0.660)$ & $(0.525)$ & $(0.435)$ & $(0.415)$ & $(0.432)$ & $(0.498)$ & $(0.522)$ \\
\hline$<$ Control Varia & les> & & & & & & \\
\hline ASSET & $0.000^{* * *}$ & $0.000^{* * *}$ & $0.000^{* * *}$ & $0.000^{* *}$ & $0.000^{* * *}$ & $0.000^{* * *}$ & $0.000^{* * *}$ \\
\hline & $(0.000)$ & $(0.000)$ & $(0.000)$ & $(0.000)$ & $(0.000)$ & $(0.000)$ & $(0.000)$ \\
\hline LOCAL & -0.322 & -0.836 & -0.181 & 0.189 & 0.132 & -0.481 & -0.850 \\
\hline & $(0.607)$ & $(0.561)$ & (0.488) & (0.467) & $(0.516)$ & (0.543) & (0.598) \\
\hline LIGHT & -1.132 & $-1.909^{* *}$ & $-1.185^{*}$ & $-1.530^{* * *}$ & $-1.391^{* *}$ & $-1.902^{* * *}$ & $-1.984^{* *}$ \\
\hline & $(0.839)$ & $(0.758)$ & $(0.673)$ & $(0.573)$ & $(0.619)$ & $(0.706)$ & $(0.774)$ \\
\hline CHEMICAL & -1.394 & -0.430 & -0.123 & -0.312 & -0.251 & -0.211 & -0.681 \\
\hline & (1.018) & $(0.757)$ & (0.668) & (0.666) & $(0.696)$ & (0.719) & $(0.828)$ \\
\hline METAL & -1.170 & -0.426 & -0.363 & -0.245 & $-1.153^{* *}$ & -0.162 & $-1.302^{*}$ \\
\hline & $(0.776)$ & (0.697) & $(0.555)$ & (0.569) & $(0.552)$ & $(0.660)$ & $(0.712)$ \\
\hline ELECTRONICS & -1.008 & $-1.674^{* * *}$ & $-1.108^{* *}$ & -0.623 & -0.725 & $-1.314^{* *}$ & $-1.436^{* *}$ \\
\hline & $(0.703)$ & $(0.564)$ & $(0.471)$ & (0.459) & $(0.513)$ & (0.519) & $(0.571)$ \\
\hline MACHINE & 0.344 & -0.742 & -0.121 & -0.122 & 0.216 & -0.674 & -0.308 \\
\hline & $(0.654)$ & $(0.541)$ & (0.502) & (0.499) & $(0.547)$ & (0.502) & $(0.605)$ \\
\hline Constant & $-1.217^{*}$ & -0.962 & -0.368 & -0.118 & -0.502 & -1.066 & -1.213 \\
\hline & $(0.728)$ & $(0.702)$ & $(0.532)$ & $(0.528)$ & (0.599) & (0.692) & $(0.744)$ \\
\hline Observations & 87 & 80 & 80 & 87 & 80 & 87 & 87 \\
\hline Pseudo R2 & 0.444 & 0.421 & 0.235 & 0.221 & 0.274 & 0.411 & 0.474 \\
\hline
\end{tabular}

Note: ${ }^{* *} \mathrm{p}<0.01,{ }^{* *} \mathrm{p}<0.05,{ }^{*} \mathrm{p}<0.1$. Robust standard errors are in parentheses.

Note: Variable EX_LOCAL_s is dropped when it predicts dependent variable perfectly.

Source: authors. 
engineers with diversified suppliers or customers in these countries make it possible to incrementally improve $\mathrm{Q}, \mathrm{C}$, and $\mathrm{D}$ at the same time and competitiveness in the international market.

\section{Product Innovations by Firms in Calabarzon}

Table 6 shows estimated effects of exchanging engineers on product innovations implemented by the firms in Calabarzon. There are no positively significant effects on introduction of new products (PROD) as shown in the column (8).

When the new products are limited to those introduced into new markets for the respondents (MARKET), exchange of engineers with suppliers in China is positively correlated at the $1 \%$ level of significance (column (9)). The firms that introduced new products into new markets and improved quality control ( $Q$ MARKET) or reduced product defects (PD_MARKET) simultaneously have also closer face-to-face contacts with suppliers in China, as shown by the positive coefficients on this variable at the $1 \%$ levels of significance (columns (13) and (14)).

An additional finding from control variables is the non-significant effects of $R \& D$ on the introduction of new products into new markets. This indicates firms in developing countries can introduce new products without expensive R\&D investments, combining new ideas and existing technologies in cooperation with engineers from their suppliers.

In the case of new products based on new technologies (TECH), the firms that introduced such new products have closer contacts with customers in Japan (column (10)). Positively significant coefficients on customers in Japan are estimated when the firms in Calabarzon improve quality control ( $Q T E C H$ ) or decrease product defects (PD_TECH), introducing new technology-based products (columns (15) and (16)). Therefore, firms in Calabarzon can benefit from their collaboration with customers in Japan that motivate firms in the Philippines to be innovative or that provide technical support to introduce new products. Customers in Japan also seek firms in Calabarzon to launch new products keeping quality controls and/or minimizing product defects.

Firms in China are also important collaborators for firms in Calabarzon when the latter look for new products based on new technologies (columns (10) and (15)). This indicates that firms in the Philippines can benefit from intensive exchange of information with suppliers in China to go into timely 


\section{Table 6}

Effects of Exchanging Engineer with Main Customer and Supplier on Product Innovations by Firms in Calabarzon

\begin{tabular}{|c|c|c|c|c|c|c|c|c|c|}
\hline & (8) & (9) & (10) & (11) & (12) & (13) & (14) & (15) & (16) \\
\hline & $P R O D$ & MARKET & TECH & QPROD & $P D_{-}$ & Q & $P D_{-}$ & Q $T E C H$ & PD_TECH \\
\hline & & & & & PROD & MARKET & MARKET & & \\
\hline \multicolumn{10}{|l|}{$\langle\mathrm{EX}\rangle$} \\
\hline \multirow[t]{2}{*}{ EX_LOCAL_c } & -0.404 & $-1.700^{* * *}$ & -0.408 & $-0.653^{* *}$ & -0.380 & $-1.714^{* * *}$ & $-1.222^{* *}$ & -0.813 & -0.594 \\
\hline & $(0.315)$ & $(0.628)$ & $(0.470)$ & $(0.314)$ & (0.319) & $(0.611)$ & $(0.503)$ & $(0.561)$ & $(0.527)$ \\
\hline \multirow[t]{2}{*}{ EX_JP_c } & 0.400 & 1.143 & $1.252^{* *}$ & 0.285 & 0.560 & 1.223 & 1.134 & $1.253^{* *}$ & $1.245^{* *}$ \\
\hline & $(0.442)$ & $(0.858)$ & $(0.562)$ & $(0.468)$ & $(0.454)$ & $(0.887)$ & $(0.870)$ & $(0.574)$ & $(0.568)$ \\
\hline \multirow[t]{2}{*}{ EX_LOCAL_s } & 0.228 & 1.194 & 0.388 & 0.300 & 0.256 & $1.229^{*}$ & 0.830 & 0.671 & 0.586 \\
\hline & $(0.514)$ & $(0.739)$ & $(0.582)$ & $(0.481)$ & $(0.466)$ & $(0.725)$ & $(0.684)$ & (0.645) & $(0.633)$ \\
\hline \multirow[t]{2}{*}{ EX_JP_s } & 0.418 & 0.234 & -0.481 & -0.054 & 0.164 & -0.213 & -0.147 & -0.435 & -0.382 \\
\hline & $(0.456)$ & $(0.868)$ & $(0.546)$ & $(0.486)$ & $(0.474)$ & $(0.889)$ & (0.891) & $(0.560)$ & $(0.555)$ \\
\hline \multirow[t]{2}{*}{ EX_CN_s } & 0.575 & $2.721^{* * *}$ & $1.056^{*}$ & 0.788 & 0.274 & $2.753^{* * *}$ & $1.802^{* * *}$ & $1.283^{* *}$ & 0.599 \\
\hline & $(0.538)$ & $(0.692)$ & $(0.595)$ & $(0.556)$ & $(0.570)$ & $(0.675)$ & (0.699) & (0.621) & $(0.721)$ \\
\hline \multicolumn{10}{|c|}{$\langle$ Control Variables $\rangle$} \\
\hline \multirow[t]{2}{*}{$\mathrm{R} \& \mathrm{D}$} & $1.099^{* * * *}$ & 0.327 & $0.637^{* *}$ & $0.820^{* * * *}$ & $0.621^{* *}$ & 0.358 & 0.251 & $0.659^{* *}$ & $0.653^{* *}$ \\
\hline & $(0.286)$ & $(0.400)$ & $(0.302)$ & $(0.267)$ & $(0.268)$ & $(0.402)$ & $(0.411)$ & $(0.306)$ & $(0.326)$ \\
\hline \multirow[t]{2}{*}{ ASSET } & $0.000^{* *}$ & $0.000^{* * *}$ & -0.000 & $0.000^{* *}$ & $0.000^{* * *}$ & $0.000^{* * *}$ & $0.000^{* * *}$ & -0.000 & -0.000 \\
\hline & $(0.000)$ & $(0.000)$ & $(0.000)$ & $(0.000)$ & $(0.000)$ & $(0.000)$ & $(0.000)$ & $(0.000)$ & $(0.000)$ \\
\hline \multirow[t]{2}{*}{ LOCAL } & 0.142 & $2.039^{* * *}$ & 0.210 & 0.006 & 0.219 & $2.045^{* * *}$ & $2.136^{* * * *}$ & 0.071 & 0.359 \\
\hline & $(0.253)$ & $(0.564)$ & $(0.357)$ & $(0.253)$ & $(0.252)$ & $(0.564)$ & $(0.570)$ & $(0.350)$ & (0.353) \\
\hline \multirow[t]{2}{*}{ LIGHT } & -0.001 & -0.652 & -0.430 & -0.226 & -0.155 & -0.637 & -0.778 & -0.419 & $-0.785^{*}$ \\
\hline & $(0.344)$ & (0.618) & $(0.429)$ & (0.341) & $(0.335)$ & (0.619) & $(0.600)$ & $(0.424)$ & $(0.418)$ \\
\hline \multirow[t]{2}{*}{ CHEMICAL } & 0.081 & -0.519 & 0.199 & 0.087 & -0.093 & -0.333 & -0.427 & 0.263 & 0.118 \\
\hline & $(0.433)$ & $(0.662)$ & $(0.488)$ & $(0.428)$ & $(0.428)$ & (0.659) & (0.633) & (0.490) & $(0.475)$ \\
\hline \multirow[t]{2}{*}{ METAL } & -0.359 & -0.135 & -0.239 & -0.470 & -0.560 & -0.080 & -0.409 & -0.199 & -0.643 \\
\hline & $(0.453)$ & $(0.680)$ & $(0.482)$ & $(0.446)$ & $(0.442)$ & $(0.667)$ & (0.729) & $(0.494)$ & $(0.582)$ \\
\hline \multirow[t]{2}{*}{ ELECTRONICS } & 0.507 & 0.402 & $0.776^{*}$ & 0.048 & 0.219 & 0.362 & 0.301 & 0.614 & 0.544 \\
\hline & $(0.412)$ & $(0.616)$ & $(0.435)$ & $(0.399)$ & $(0.388)$ & $(0.619)$ & $(0.592)$ & $(0.434)$ & $(0.430)$ \\
\hline \multirow[t]{2}{*}{ MACHINE } & $0.892^{*}$ & & -0.585 & $1.057^{* *}$ & 0.741 & & & -0.655 & -0.680 \\
\hline & $(0.492)$ & & $(0.579)$ & $(0.497)$ & $(0.500)$ & & & $(0.584)$ & $(0.577)$ \\
\hline \multirow[t]{2}{*}{ Constant } & $-0.699^{* *}$ & $-3.351^{* * *}$ & $-1.432^{* * *}$ & -0.531 & $-0.766^{* *}$ & $-3.364^{* * *}$ & $-3.348^{* * *}$ & $-1.322^{* * *}$ & $-1.464^{* * *}$ \\
\hline & $(0.330)$ & $(0.600)$ & $(0.398)$ & $(0.326)$ & $(0.319)$ & $(0.611)$ & $(0.607)$ & $(0.385)$ & $(0.384)$ \\
\hline Observations & 157 & 140 & 157 & 157 & 157 & 140 & 140 & 157 & 157 \\
\hline Pseudo R2 & 0.233 & 0.358 & 0.189 & 0.200 & 0.183 & 0.336 & 0.296 & 0.201 & 0.221 \\
\hline
\end{tabular}

Note: ${ }^{* * *} \mathrm{p}<0.01,{ }^{* *} \mathrm{p}<0.05,{ }^{*} \mathrm{p}<0.1$. Robust standard errors are in parentheses.

Note: Variable MACHINE is dropped when it predicts dependent variable perfectly.

Source: authors. 
commercial production of new products. This also implies that suppliers in China are enhancing their capabilities of development and can provide parts, components or equipment necessary for new products launched in the Philippines. As it is said, the manufacturing sector in China is fostering research and development, receiving support from the government and hosting foreign direct investment in design centers.

Contrary to the foreign sources of knowledge, roles of domestic customers and suppliers in product innovations are limited. Only the coefficient of 1.229 on the effect of exchanging engineers with domestic suppliers is significant at the $10 \%$ level (column (13)).in of Table 6. This result suggests that the firms in Calabarzon who exchange engineers with their domestic suppliers are more likely to introduce new products into new markets and improve quality control simultaneously.

\section{Integration of Local Innovation Systems into Asian Innovation System}

The empirical results in the previous section indicate that firms in Southeast Asia can make use of multi-sources of knowledge and technologies available in Southeast and East Asia to improve innovations in processes and products with certainty and at a lower cost. In other words, they take advantage of agglomeration effects, production networks, and the gaps in industrial development and innovation capabilities in Southeast and East Asia.

To absorb essential know-how on improving QCD performances, firms in less developed countries like Cambodia, Lao PDR, and Vietnam can receive technical assistance from firms in the same industrial districts or neighboring countries. In the past, Japanese FDI has been a main source of technology transfer. Agglomeration triggered by FDI has established local cooperation between MNCs and local firms in addition to intrinsic cooperation among local firms. FDI also have linked innovation systems in home countries with those in host countries to facilitate technology transfers. Moreover, recently intra-regional FDI within ASEAN or from China to ASEAN is increasing. Such South-South FDI is becoming an important source of technologies for less developed countries.

There is evidence on South-South technology transfer. So called "China plus One" strategy introduced by Japanese firms in China is an example. A Japanese firm in Guangdong, China, producing domestic sewing machines 
established a factory in Hanoi to transfer a production line from China. When the firm started its factory operation in Hanoi, it dispatched Chinese engineers to Hanoi and trained Vietnamese blue-collar workers in Guangdong. By using international bus services for moving them, the firm could transfer necessary technologies and associated tacit knowledge at a lower cost through face-to-face communications (Ueki, 2010; Machikita et al., 2010). In case of a Japanese motorcycle manufacturer in Thailand, they provide technical supports from Thailand to Lao PDR and other surrounding nations, dispatching Thai engineers and managers (Intarakumnerd and Fujita, 2008).

The empirical analyses in this paper verified such South-South cooperation when firms in Calabarzon introduce new products into new markets, which necessitate less advanced technologies. In addition, the estimation results verified that when firms in Calabarzon adopt new technologies for introducing new products, North-South technical cooperation are still demanded; they still need technology transfer from advanced countries like Japan.

Facilitation of engineer mobility through infrastructure development and economic integration promote intra-regional technology transfer within Southeast and East Asia. Initiatives for Asian economic integration will enable firms to move up technological ladders by combining more diversified knowledge accumulated in local innovation systems in Asia (Figure 3).

\section{Figure 3}

Technology Ladder and Economic Integration

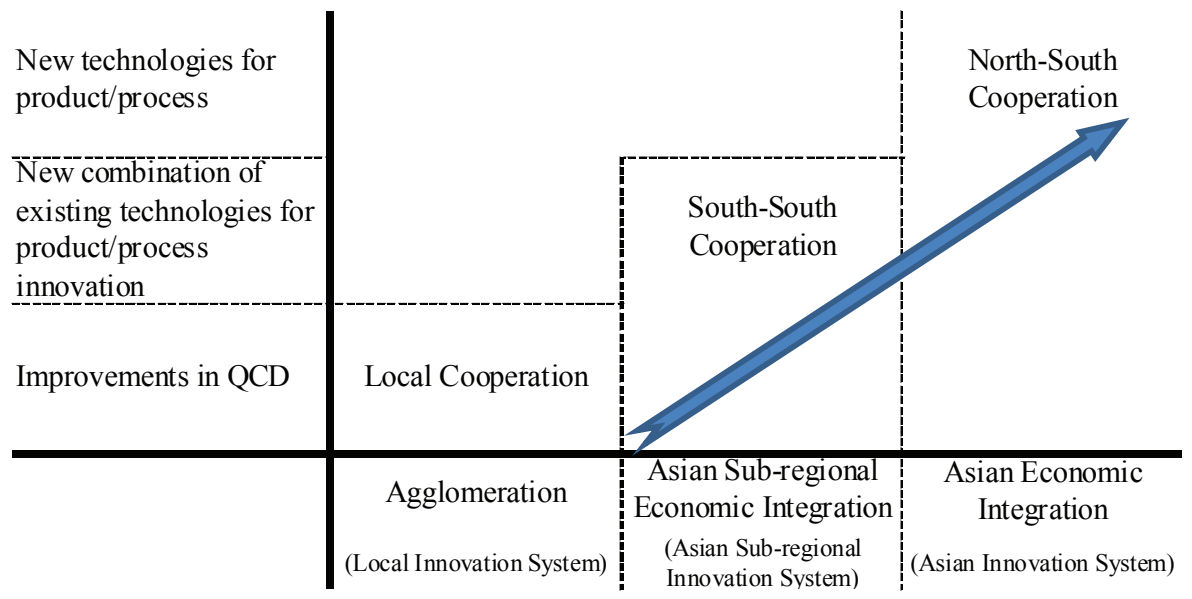

Source: authors. 
This empirical study focuses only on the Philippines and Vietnam. But the importance of China as a source of parts and components has increased for main industrializing countries in ASEAN. In the Asian innovation system, firms in the coastal area of China can play a significant role in technology transfer necessary to combine new ideas and existing technologies. On the other hand, Japan is still one of the main sources for several ASEAN countries. Therefore, Japan still plays a leading role in diffusing technologies to ASEAN.

Table 7

Imports of Parts and Components from China and Japan in 2000 and 2008

\begin{tabular}{|c|c|c|c|c|c|c|}
\hline \multirow[b]{2}{*}{ Importer } & \multirow[b]{2}{*}{ Origin } & \multicolumn{2}{|c|}{ Value (US\$ million) } & \multirow{2}{*}{$\begin{array}{c}\text { Growth } \\
2008 / 2000\end{array}$} & \multicolumn{2}{|c|}{ Share (\%) } \\
\hline & & 2000 & 2008 & & 2000 & 2008 \\
\hline \multirow[t]{3}{*}{ Cambodia } & China & 2.7 & 51.7 & 19.3 & 6.6 & 29.8 \\
\hline & Japan & 4.0 & 11.8 & 3.0 & 9.9 & 6.8 \\
\hline & World & 40.4 & 173.6 & 4.3 & 100 & 100 \\
\hline \multirow[t]{3}{*}{ Indonesia } & China & 143.0 & $2,547.4$ & 17.8 & 3.1 & 12.1 \\
\hline & Japan & $2,080.4$ & $5,558.7$ & 2.7 & 45.2 & 26.4 \\
\hline & World & $4,607.1$ & $21,043.8$ & 4.6 & 100 & 100 \\
\hline \multirow[t]{3}{*}{ Malaysia } & China & 961.7 & $6,664.8$ & 6.9 & 2.4 & 14.5 \\
\hline & Japan & $8,436.5$ & $6,016.6$ & 0.7 & 21.3 & 13.1 \\
\hline & World & $39,536.8$ & $46,000.0$ & 1.2 & 100 & 100 \\
\hline \multirow[t]{3}{*}{ Philippines } & China & 145.5 & $1,567.1$ & 10.8 & 0.9 & 6.9 \\
\hline & Japan & $4,264.6$ & $4,144.9$ & 1.0 & 25.0 & 18.4 \\
\hline & World & $17,058.2$ & $22,580.2$ & 1.3 & 100 & 100 \\
\hline \multirow[t]{3}{*}{ Thailand } & China & 928.4 & $4,532.4$ & 4.9 & 4.8 & 12.8 \\
\hline & Japan & $6,194.9$ & $11,315.3$ & 1.8 & 32.1 & 31.9 \\
\hline & World & $19,268.7$ & $35,421.0$ & 1.8 & 100 & 100 \\
\hline \multirow[t]{3}{*}{ Vietnam } & China & 64.0 & 1,383.6 & 21.6 & 3.6 & 17.9 \\
\hline & Japan & 808.3 & $1,895.7$ & 2.3 & 46.1 & 24.5 \\
\hline & World & $1,753.8$ & $7,732.7$ & 4.4 & 100 & 100 \\
\hline
\end{tabular}

Note: Parts and Components include UN BEC codes 42 and 53.

Source: un Comtrade. 


\section{Conclusion}

This paper attempts to detect sources of new technologies transferred to Southeast Asia, using firm-level data from a survey to manufacturing firms. Face-to-face communications among engineers are emphasized as a potential channel of technology and knowledge transfer. This paper also verify differences in sources of new technologies according to innovation types and absorptive capacity levels, by comparing two industrial districts in different development stages; one is a well-established industrial district in Calabarzon, Philippines and the other is a rapid growing agglomeration in Hanoi, Vietnam.

We find significant effects of exchange of engineers with customers in Vietnam and Japan and suppliers in Vietnam and China on improvements in QCD performances by firms in Hanoi. On the other hand, exchange of engineers with customers in Japan and suppliers in China significantly affects improvements in production and quality control of new products by firms in Calabarzon.

The different effects on innovations in processes and products of exchanging engineers between the two industrial districts may reflect difference in the development stages. Economic integration and infrastructure development enables firms in Southeast Asia to combine various sources of technologies and knowledge at a lower cost in a more efficient manner. આy

\section{References}

Ariff, M. (Ed.) (2008), "Analyses of Industrial Agglomeration, Production Networks and FDI Promotion”, ERIA Research Project Report 2007, No. 3, Chiba: IDE/JETRO.

Cohen, W. M., and D. A. Levinthal (1990), "Absorptive Capacity: A New Perspective of Learning and Innovation", Administrative Science Quarterly, 35(1), pp. 128-152.

Foster, L., J. Haltiwanger, and C. J. Krizan (2001), "Aggregate Productivity Growth: Lessons from Microeconomic Evidence”, in Dean, E., M. Harper, and C. Hulten (Eds.), New Directions in Productivity Analysis, University of Chicago Press.

Hamilton, B., J. Nickerson, and H. Owan (2003), "Team Incentives and Worker Heterogeneity: An Empirical Analysis of the Impact of Teams on Productivity and Participation", Journal of Political Economy, 111(3), pp. 465-497. 
Ichiniowski, C., K. Shaw, and G. Prennushi (1997), "The Effects of Human Resource Management Practices on Productivity: A Study of Steel Finishing Lines", American Economic Review, 87(3), pp. 291-313.

Intarakumnerd, P. (Ed.) (2010), "Fostering Production and Science \& Technology Linkages to Stimulate Innovation in ASEAN, ERIA Research Project Report 2009, No. 7-4, Jakarta: Economic Research Institute for ASEAN and East Asia (ERIA).

Intarakumnerd, P., and M. Fujita (2008), "Coping with a Giant: Challenges and Opportunities for Thai and Vietnamese Motorcycle Industry from China", Science, Technology \& Society, 13(1), pp. 35-60.

Kagami, M. (Ed.) (2010), "Economic Relations of China, Japan and Korea with the Mekong River Basin Countries (MRBCs), BRC Research Report, No. 3, Bangkok: Bangkok Research Center (IDE/JETRO).

Kimura, F. (2009), "The Spatial Structure of Production/Distribution Networks and its Implication for Technology Transfers and Spillovers", ERIA Discussion Paper, No. 2009-02, Jakarta: ERIA.

Kuchiki, A., and M. Tsuji (Eds.) (2008), The Flowchart Approach to Industrial Cluster Policy, Basingstoke: Palgrave Macmillan.

Lentz, R., and D. T. Mortensen (2008), "An Empirical Model of Growth Through Product Innovation”, Econometrica, 76(6), pp. 1317-1373.

Limskul, K. (Ed.) (2009), "Development of Regional Production and Logistics Networks in East Asia”, ERIA Research Project Report 2008, No. 4-1, Jakarta: ERIA.

Machikita, T., and Y. Ueki (2010a), "Spatial Architecture of the Production Networks in Southeast Asia”, ERIA Discussion Paper, No. 2010-01, Jakarta: ERIA.

—— (2010b), "Search-theoretic Approach to Securing New Suppliers: Impacts of Geographic Proximity for Importer and Non-importer", ERIA Discussion Paper, No. 2010-02, Jakarta: ERIA.

- - (2010c), "Innovation in Linked and Non-linked Firms: Effects of Variety of Linkages in East Asia", ERIA Discussion Paper, No. 2010-03, Jakarta: ERIA.

- - (2010d), "The Impacts of Face-to-face and Frequent Interactions on Innovation: Upstream-Downstream Relations”, ERIA Discussion Paper, No. 2010-04, Jakarta: ERIA.

Machikita, T., B. Truong, and Y. Ueki (2010), “Technology Transfer to Vietnam through Engineer Exchanges under 'China plus One’ Strategy: Firm-level 
Evidence", Proceedings of the 3rd Vietnamese Economist Annual Meeting (VEAM 2010).

Mas, A., and E. Moretti (2009), "Peers at Work", American Economic Review, 99(1), pp. 112-145.

Polanyi, M. (1966), "The Logic of Tacit Inference", Philosophy, The Journal of the Royal Institute of Philosophy, 41(155), pp. 1-18.

- - (1967), The Tacit Dimension, University of Chicago Press.

Saxenian, A. (1996), Regional Advantage: Culture and Competition in Silicon Valley and Route 128, Harvard.

- - (2006), The New Argonauts: Regional Advantage in a Global Economy, Harvard.

Truong, B. (2008), "Factors of Agglomeration in Vietnam and Recommendations", in Ariff (Ed.) (2008), pp. 155-189.

- - (2010), "The Process of Improving Technology and the Perspective of Domestic Suppliers in the Motorbike Industry in Hanoi", in Intarakumnerd (Ed.), pp. 271-305.

Ueki, Y. (2010), “Complementary Manufacturing Relationships between Firms in China and CLMV", in Kagami (Ed.), pp. 328-363.

\section{Appendix}

Table A1

List of Variables

\begin{tabular}{|c|c|}
\hline Variable & Definition \\
\hline \multicolumn{2}{|c|}{ Dependent Variables } \\
\hline STAN & $\begin{array}{l}\text { Coded } 1 \text { if a firm adopted an international standard between } 2006 \text { and } \\
2008\end{array}$ \\
\hline Q & $\begin{array}{l}\text { Coded } 1 \text { if a firm improved quality of products substantially between } 2007 \\
\text { and } 2008\end{array}$ \\
\hline PD & $\begin{array}{l}\text { Coded } 1 \text { if a firm reduced product defects substantially between } 2007 \text { and } \\
2008\end{array}$ \\
\hline C & $\begin{array}{l}\text { Coded } 1 \text { if a firm decreased production cost substantially between } 2007 \text { and } \\
2008\end{array}$ \\
\hline $\mathrm{D}$ & $\begin{array}{l}\text { Coded } 1 \text { if a firm reduced lead-time (the period between a customer's order } \\
\text { and delivery of product) between } 2007 \text { and } 2008\end{array}$ \\
\hline QC & Coded 1 if $Q=1$ and $C=1$ \\
\hline $\mathrm{QCD}$ & Coded 1 if $Q=1$ and $C=1$ and $D=1$ \\
\hline
\end{tabular}




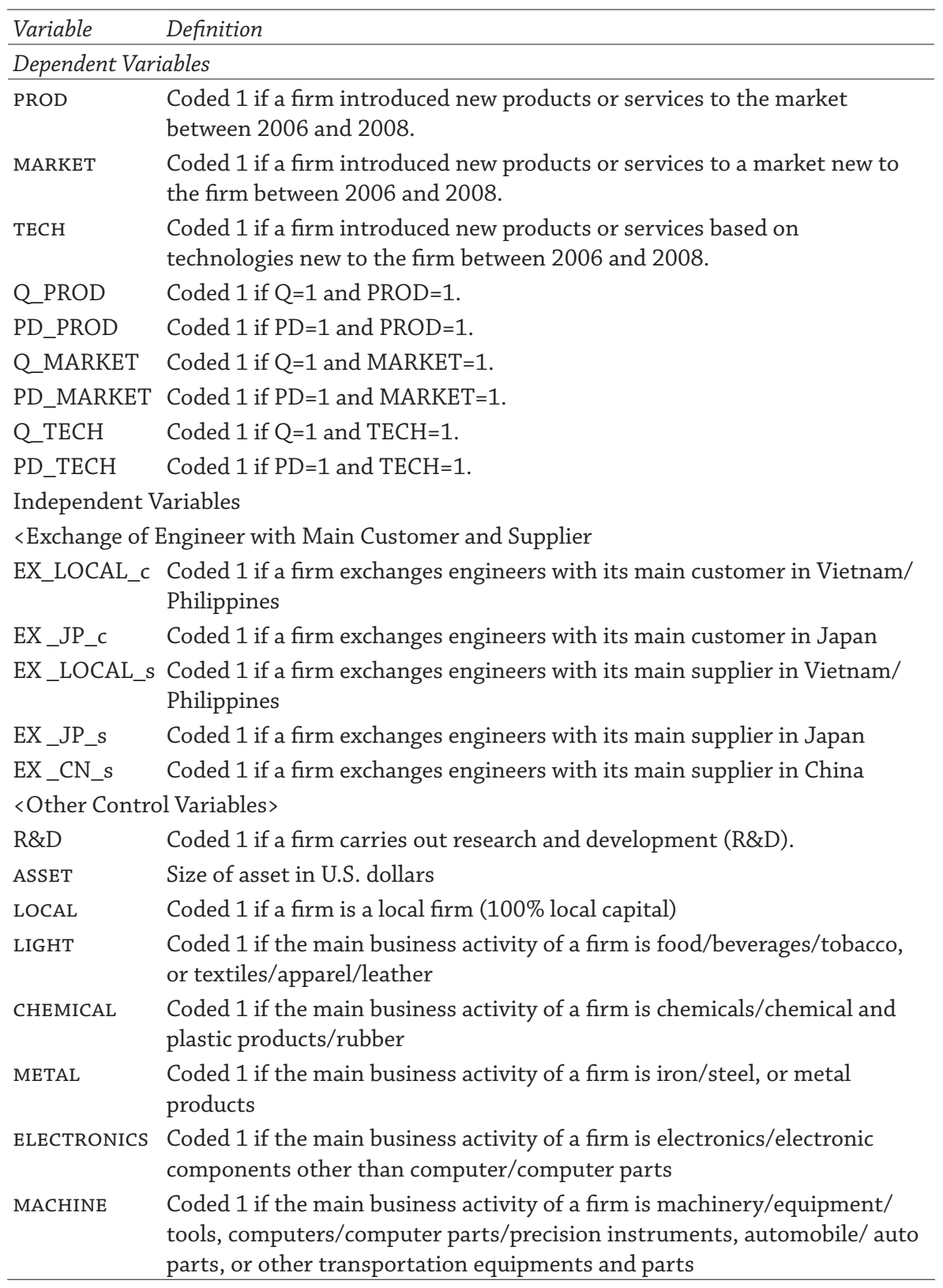

Source: authors. 
Table A2

Effects of Exchanging Engineer with Main Customer and Supplier on Process Innovations by Firms in Calabarzon

\begin{tabular}{|c|c|c|c|c|c|c|c|}
\hline & (1) & (2) & (3) & (4) & (5) & (6) & (7) \\
\hline & STAN & $Q$ & $P D$ & C & $D$ & $Q C$ & $Q C D$ \\
\hline \multicolumn{8}{|l|}{$\langle\mathrm{EX}\rangle$} \\
\hline \multirow[t]{2}{*}{ EX_LOCAL_c } & 0.237 & -0.246 & 0.140 & 0.479 & 0.159 & 0.417 & 0.347 \\
\hline & $(0.348)$ & $(0.344)$ & $(0.335)$ & $(0.334)$ & $(0.314)$ & $(0.328)$ & $(0.331)$ \\
\hline \multirow[t]{2}{*}{$E X \_J P \_c$} & -0.520 & 0.070 & 0.605 & 0.588 & 0.351 & 0.460 & 0.245 \\
\hline & $(0.761)$ & $(0.529)$ & $(0.495)$ & $(0.478)$ & $(0.492)$ & $(0.466)$ & $(0.461)$ \\
\hline \multirow[t]{2}{*}{ EX_LOCAL_s } & -0.551 & 0.255 & 0.248 & -0.487 & $0.920^{* *}$ & -0.377 & -0.499 \\
\hline & $(0.484)$ & $(0.498)$ & $(0.480)$ & $(0.464)$ & $(0.442)$ & $(0.464)$ & $(0.491)$ \\
\hline \multirow[t]{2}{*}{ EX_JP_s } & 0.054 & $-0.902^{*}$ & -0.473 & -0.102 & 0.063 & -0.138 & 0.155 \\
\hline & $(0.764)$ & $(0.540)$ & $(0.492)$ & $(0.495)$ & $(0.492)$ & $(0.481)$ & $(0.466)$ \\
\hline \multirow[t]{2}{*}{ EX_CN_s } & & -0.259 & -0.425 & -0.662 & -0.427 & -0.587 & -0.311 \\
\hline & & $(0.697)$ & $(0.575)$ & $(0.594)$ & $(0.587)$ & $(0.615)$ & $(0.620)$ \\
\hline \multicolumn{8}{|c|}{$\langle$ Control Variables $\rangle$} \\
\hline \multirow[t]{2}{*}{ ASSET } & $0.000^{* * *}$ & 0.000 & 0.000 & 0.000 & -0.000 & 0.000 & 0.000 \\
\hline & $(0.000)$ & $(0.000)$ & $(0.000)$ & $(0.000)$ & $(0.000)$ & $(0.000)$ & $(0.000)$ \\
\hline \multirow[t]{2}{*}{ LOCAL } & $-0.773^{* * *}$ & $-0.617^{* *}$ & -0.070 & 0.091 & 0.046 & -0.004 & -0.145 \\
\hline & $(0.263)$ & $(0.270)$ & $(0.243)$ & $(0.258)$ & $(0.240)$ & $(0.259)$ & $(0.278)$ \\
\hline \multirow[t]{2}{*}{ LIGHT } & -0.510 & -0.434 & -0.033 & 0.401 & -0.198 & 0.317 & 0.401 \\
\hline & $(0.355)$ & $(0.372)$ & $(0.355)$ & (0.393) & $(0.339)$ & $(0.392)$ & $(0.462)$ \\
\hline \multirow[t]{2}{*}{ CHEMICAL } & 0.713 & 0.219 & 0.024 & 0.289 & 0.251 & 0.304 & 0.733 \\
\hline & $(0.452)$ & $(0.515)$ & $(0.455)$ & $(0.472)$ & $(0.423)$ & $(0.472)$ & $(0.524)$ \\
\hline \multirow[t]{2}{*}{ METAL } & 0.061 & -0.255 & -0.206 & 0.484 & 0.261 & 0.339 & $0.823^{*}$ \\
\hline & $(0.465)$ & $(0.457)$ & $(0.415)$ & $(0.426)$ & $(0.407)$ & $(0.431)$ & $(0.482)$ \\
\hline \multirow[t]{2}{*}{ ELECTRONICS } & $1.354^{* *}$ & -0.360 & 0.230 & 0.459 & 0.497 & 0.449 & 0.789 \\
\hline & $(0.569)$ & $(0.482)$ & $(0.461)$ & $(0.438)$ & $(0.403)$ & $(0.433)$ & $(0.488)$ \\
\hline \multirow[t]{2}{*}{ MACHINE } & $1.018^{* *}$ & 0.591 & 0.398 & $1.311^{* * *}$ & 0.385 & $1.156^{* *}$ & $1.373^{* * *}$ \\
\hline & $(0.483)$ & $(0.606)$ & $(0.531)$ & $(0.498)$ & $(0.460)$ & $(0.490)$ & $(0.529)$ \\
\hline \multirow[t]{2}{*}{ Constant } & -0.192 & $1.575^{* * *}$ & 0.549 & $-1.201^{* * *}$ & -0.047 & $-1.118^{* * *}$ & $-1.385^{* * *}$ \\
\hline & $(0.351)$ & $(0.381)$ & $(0.361)$ & $(0.369)$ & $(0.328)$ & $(0.367)$ & $(0.420)$ \\
\hline Observations & 151 & 157 & 157 & 157 & 157 & 157 & 157 \\
\hline Pseudo R2 & 0.353 & 0.0840 & 0.0429 & 0.101 & 0.0700 & 0.0819 & 0.114 \\
\hline
\end{tabular}

Note: ${ }^{* * *} \mathrm{p}<0.01,{ }^{* *} \mathrm{p}<0.05,{ }^{*} \mathrm{p}<0.1$. Robust standard errors are in parentheses. Note: Variable EX_CN_s is dropped when it predicts dependent variable perfectly. Source: authors. 


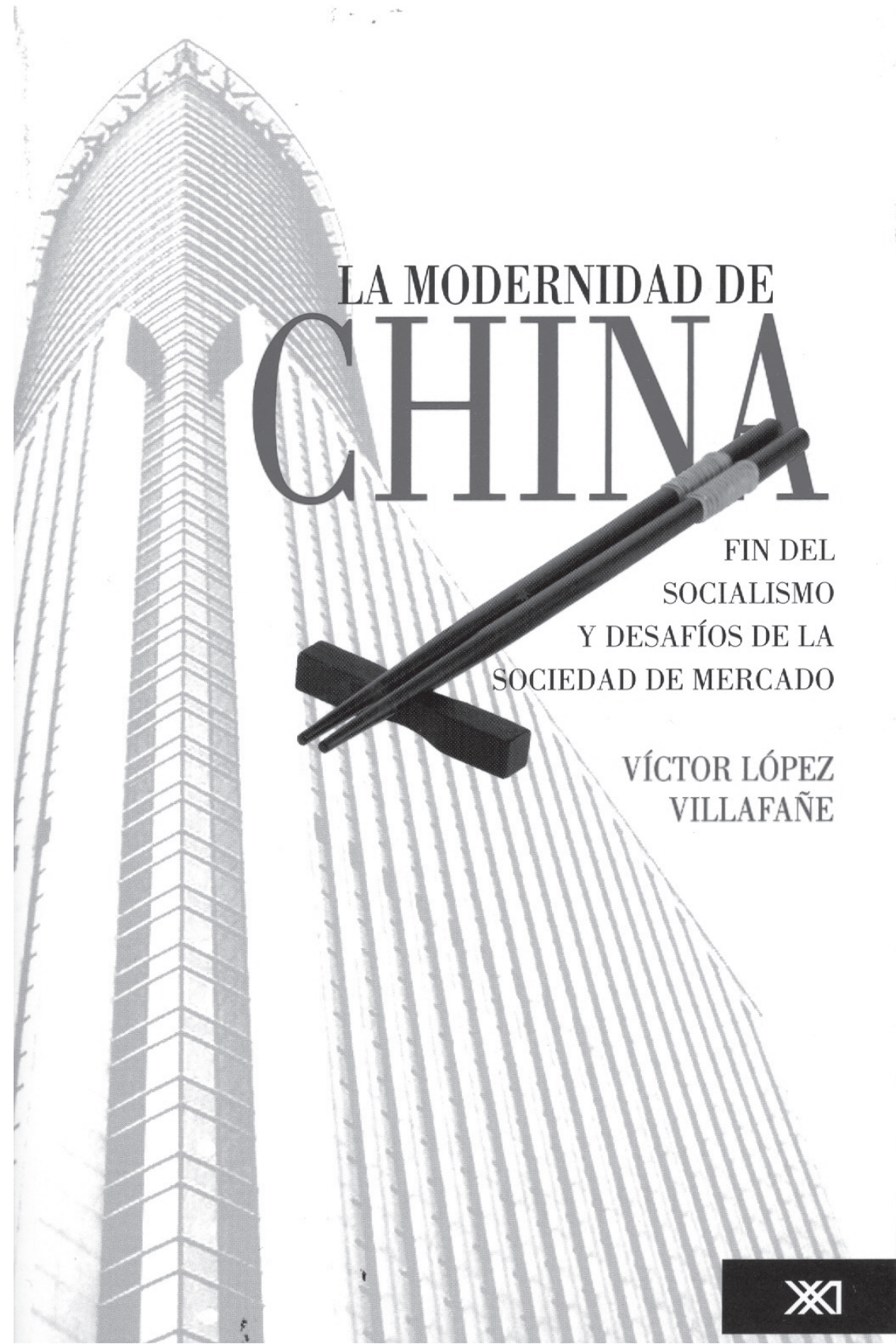

